\title{
The type 2 iodothyronine deiodinase is essential for adaptive thermogenesis in brown adipose tissue
}

\author{
Lucia A. de Jesus, ${ }^{1}$ Suzy D. Carvalho, ${ }^{1}$ Mirian O. Ribeiro, ${ }^{2}$ Mark Schneider, ${ }^{3}$ \\ Sung-Woo Kim, ${ }^{1}$ John W. Harney, ${ }^{1}$ P. Reed Larsen, ${ }^{1}$ and Antonio C. Bianco ${ }^{1}$ \\ ${ }^{1}$ Thyroid Division, Department of Medicine, Brigham and Women's Hospital and Harvard Medical School, \\ Boston, Massachusetts, USA \\ ${ }^{2}$ Department of Physiology and Biophysics, Institute of Biomedical Sciences, University of Sao Paulo, Sao Paulo, Brazil \\ ${ }^{3}$ Department of Physiology, Dartmouth Medical School, Lebanon, New Hampshire, USA \\ Address correspondence to: Antonio C. Bianco, Brigham and Women's Hospital, \\ 77 Avenue Louis Pasteur, HIM Building, Room 550, Boston, Massachusetts 02115, USA. \\ Phone: (617) 525-5158; Fax: (617) 731-4718; E-mail: abianco@rics.bwh.harvard.edu.
}

Received for publication July 20, 2001, and accepted in revised form September 10, 2001.

Type 2 iodothyronine deiodinase (D2) is a selenoenzyme, the product of the recently cloned cAMPdependent Dio2 gene, which increases 10- to 50-fold during cold stress only in brown adipose tissue (BAT). Here we report that despite a normal plasma 3,5,3'-triiodothyronine (T3) concentration, coldexposed mice with targeted disruption of the $\mathrm{Dio} 2$ gene $\left(\mathrm{Dio}^{-/-}\right)$become hypothermic due to impaired BAT thermogenesis and survive by compensatory shivering with consequent acute weight loss. This occurs despite normal basal mitochondrial uncoupling protein 1 (UCP1) concentration. In Dio2 $2^{-/-}$ brown adipocytes, the acute norepinephrine-, CL316,243-, or forskolin-induced increases in lipolysis, UCP1 mRNA, and $\mathrm{O}_{2}$ consumption are all reduced due to impaired cAMP generation. These hypothyroid-like abnormalities are completely reversed by a single injection of T3 14 hours earlier. Recent studies suggest that UCP1 is primarily dependent on thyroid hormone receptor $\beta$ (TR $\beta$ ) while the normal sympathetic response of brown adipocytes requires TR $\alpha$. Intracellularly generated T3 may be required to saturate the $T R \alpha$, which has an approximately fourfold lower T3-binding affinity than does TR $\beta$. Thus, D2 is an essential component in the thyroid-sympathetic synergism required for thermal homeostasis in small mammals.

J. Clin. Invest. 108:1379-1385 (2001). DOI:10.1172/JCI200113803.

\section{Introduction}

Most homeotherms maintain body temperature by increasing heat production in response to cold. This process, adaptive thermogenesis, is achieved by shivering or by uncoupling oxidative phosphorylation in brown adipose tissue (BAT) through uncoupling protein 1 (UCP1). The latter process is used in human newborns and other smaller mammals. BAT thermogenesis is activated by the hypothalamus via the sympathetic nervous system (SNS) (1-4). The norepinephrine-induced (NEinduced) increase in cAMP rapidly activates lipolysis, initiating mitochondrial heat production, and increases intracellular thyroxine (T4) activation to 3,5,3'-triiodothyronine (T3) via the type 2 iodothyronine deiodinase (D2) (5). BAT is a target of thyroid hormone and has a large number of $\alpha 1$ and $\beta 1$ thyroid hormone receptors (TRs) $(6,7)$. The SNS induction of D2 activity increases $\mathrm{T} 3$ concentration in BAT four- to fivefold in only a few hours after cold exposure is initiated (8), fully saturating TR in brown adipocytes (9).

Hypothyroid animals are unable to survive cold stress due to impaired adaptive thermogenesis in BAT (10, 11). Hypothyroid rat brown adipocytes generate much less cAMP in response to various adrenergic stimulators due to changes in adrenergic receptor density, G proteins, and adenylyl cyclase expression (12-14). They also have decreased levels of UCP1, the mitochondrial protein that shunts the energy derived from mitochondrial fatty acid oxidation from ATP formation to thermogenesis (1,11, 15-18). Physiological replacement of T4, but not $\mathrm{T} 3$, rapidly restores adrenergic responsiveness, UCP1 gene expression, and BAT thermogenesis by a mechanism that is blocked by iopanoic acid (IOP). This is explained by the high D2 activity in hypothyroid BAT, which catalyzes the activation of T4 to T3 $(5,11)$. This compensates for the fall in circulating T4, since administration of only small amount of T4 to hypothyroid rats (only $25 \%$ of the daily replacement dose) increases BAT TR occupancy to about $50 \%$, almost exclusively due to locally generated T3 (19).

Recent studies indicate that the TR $\alpha 1$ isoform is required to maintain the normal adrenergic responsiveness of the brown adipocytes whereas TR $\beta$ mediates T3induced UCP1 gene expression (20). It is the adrenergic pathway that mediates the three- to fourfold increase in the activity of lipogenic enzymes observed in this tissue during cold exposure. In isolated brown adipocytes, NE stimulates lipogenesis only in the presence of $\mathrm{T} 4$, in which case it is blocked by pretreatment with IOP (21). Thus it is reasonable to hypothesize that $\mathrm{D} 2$ is required to generate the T3 from T4, which permits the normal acute thermogenic function of BAT to occur. 
Table 1

Serum concentration of T4 and T3, and BAT D2 activity of Dio2 ${ }^{-/-}$and wild-type mice exposed at $4^{\circ} \mathrm{C}$

\begin{tabular}{|c|c|c|c|c|c|c|}
\hline \multirow[t]{2}{*}{ Group } & \multicolumn{2}{|c|}{$\mathrm{T} 4(\mathrm{ng} / \mathrm{ml})$} & \multicolumn{2}{|c|}{$\mathrm{T} 3(\mathrm{ng} / \mathrm{ml})$} & \multicolumn{2}{|c|}{$\mathrm{D} 2$ (fmol T4/min/mg protein) } \\
\hline & $21^{\circ} \mathrm{C}$ & $4^{\circ} \mathrm{C}$ & $21^{\circ} \mathrm{C}$ & $4^{\circ} \mathrm{C}$ & $21^{\circ} \mathrm{C}$ & $4^{\circ} \mathrm{C}$ \\
\hline $\begin{array}{l}\text { Wild-type } \\
\text { Dio2-/- }\end{array}$ & $\begin{array}{l}41 \pm 3.5 \\
68 \pm 5.5^{\mathrm{A}}\end{array}$ & $\begin{array}{l}37 \pm 4.1 \\
71 \pm 9.2\end{array}$ & $\begin{array}{l}0.61 \pm 0.12 \\
0.57 \pm 0.10\end{array}$ & $\begin{array}{l}0.70 \pm 0.09 \\
0.62 \pm 0.08\end{array}$ & $\begin{array}{l}317 \pm 6.7 \\
\text { Below BG }\end{array}$ & $\begin{array}{c}5517 \pm 1083^{\mathrm{A}} \\
\text { Below BG }\end{array}$ \\
\hline
\end{tabular}

Values are the mean \pm SD of four to six animals per parameter. ${ }^{A} P<0.05$ versus wild-type animals by ANOVA. BG, background

To define the physiological role of $\mathrm{D} 2$ in adaptive thermogenesis and function of brown adipocytes, mice with targeted disruption of the Dio2 gene (22) were studied. D2 was found to be an essential component of the thyroid-sympathetic synergism and adaptive thermogenesis.

\section{Methods}

Animals and drugs. All experiments were performed under a protocol approved by the Harvard Medical School Standing Committee on Animals. All drugs and reagents, unless otherwise specified, were purchased from Calbiochem-Novabiochem Corp. (San Diego, California, USA) or Sigma Chemical Co. (St. Louis, Missouri, USA). CL316,243 was a gift from K. Steiner (Wyeth-Ayerst Research, Princeton, New Jersey, USA). Mice with targeted disruption of the Dio2 gene were developed in a C57BL/6-129SV strain background by replacement of the sequence encoding amino acids 74-266 and part of the $3^{\prime}$ untranslated region (nucleotides 2769 in accession no. MN 010050) with a neomycin resistance cassette (22). D2 activity is absent in brain, pituitary gland, and BAT of Dio2 $2^{-/}$mice (22). Wild-type animals, with the same genetic background, were used as controls. In all studies, the genotype was confirmed by the absence of pituitary D2 activity (23). Animals were of both sexes, approximately 2 months old, and weighed 20-26 g at the time of the experiments. Control animals were housed at $21^{\circ} \mathrm{C}$ whereas cold exposure was at $4^{\circ} \mathrm{C}$ and lasted up to 24 hours. Regardless of ambient temperature, they were housed in individual plastic cages, light cycles were of 12 hours, and access to food and water was ad libitum. Core temperature was measured using a YSI 423 colonic probe (Yellow Springs Instrument Co., Yellow Springs, Ohio, USA) connected to a high-precision thermometer (YSI Precision 4000A Thermometer; Yellow Springs Instrument Co.). To measure temperature changes in interscapular BAT (IBAT) in response to NE infusion, animals were anesthetized with a mixture of urethane $(560 \mathrm{mg} / \mathrm{kg})$ and chloralose $(38 \mathrm{mg} / \mathrm{kg})$ given intraperitoneally the morning of the experiment and kept on a warm $\left(30^{\circ} \mathrm{C}\right)$ pad throughout the experiment. A polyethylene (P-50) cannula was inserted into the left jugular vein for $\mathrm{NE}$ infusion. IBAT temperatures were measured using a precalibrated thermistor probe (YSI 427; Yellow Springs Instrument Co.) secured under the brown fat pad. IBAT temperature was monitored during a period of $10 \mathrm{~min}$ utes to obtain a stable baseline prior to NE infusion. NE infusion $\left(10^{3} \mathrm{pmol} / \mathrm{min}\right)$ was performed with an infusion pump (Model 2274; Harvard Apparatus, Holliston, Massachusetts, USA) at a rate of $0.459 \mu \mathrm{l} / \mathrm{min}$.

Studies in isolated brown adipocytes. Brown adipocytes were isolated as described after minor modifications $(14,24,25)$ from $8-10$ animals per experiment. Oxygen consumption was measured in a biological oxygen monitor (YSI Model 53, Yellow Springs Instrument Co.) as described (24). Lipolysis was studied by measuring glycerol release in the incubation medium. Incubation was stopped by the addition of perchloric acid to $1 \%$ final concentration and glycerol measured as described (26). UCP1 mRNA levels were measured in isolated brown adipocytes after 6 hours' incubation. Cells were processed for RNA extraction using TRIzol Reagent according to the instructions of the manufacturer (Life Technologies Inc., Grand Island, New York, USA). Northern analysis was performed using $10 \mu \mathrm{g}$ RNA per lane and a full length mouse UCP1 CDNA kindly provided by Bradford Lowell. $28 \mathrm{~S}$ is the ribosomal RNA stained by ethidium bromide. cAMP was measured by RIA (14).

Analytical procedures. DNA and protein were measured as described $(27,28)$. Triglycerides (TGs) were quantitated after lipase digestion and glycerol measurement. Serum creatine kinase was measured by an automated ultraviolet enzymatic technique (Dade Behring Inc., Newark, Delaware, USA). Mitochondrial UCP1 levels were measured by Western blot after $5 \mu \mathrm{g}$ total mitochondrial protein was resolved in a $12 \%$ SDS-PAGE and electrotransferred to a PVDF membrane. Anti-UCP1 antiserum was a gift from J.E. Silva and was used at 1:2000 dilution. Mitochondrial COX-II gene was analyzed by Southern blot after $10 \mu \mathrm{g}$ total BAT DNA was digested with NcoI and probed with COX-II cDNA kindly provided by Bruce Spiegelman.

Statistical analysis. Comparisons were performed by Student $t$ test, and multiple comparisons were by ANOVA followed by the Student-Newman-Keuls test.

\section{Results}

Because of the important role of D2 in mediating feedback regulation of the hypothalamic-pituitary-thyroid axis by circulating T4, Dio2 $2^{-/}$animals have elevated serum concentrations of T4 but normal serum T3 (Table 1). This internal compensation permits $\mathrm{Dio2}^{-/-}$ animals to remain systemically euthyroid.

We compared the response of Dio2-/- mice to cold stress $\left(24\right.$ hours at $\left.4^{\circ} \mathrm{C}\right)$ to that of wild-type mice. As 


\section{Figure 1}

Response of Dio2 ${ }^{-/-}$and wild-type mice to cold exposure or NE infusion. All results are the mean \pm SD of 4-12 mice per time point. ${ }^{*} P<0.05$ versus wild-type time point by ANOVA. (a) Core temperature; (b) serum creatine kinase; (c) relative changes in body weight during cold exposure; (d) mitochondrial UCP1 levels by Western analysis and mitochondrial COX-II gene by Southern analysis; (e) temperature changes in IBAT in response to NE infusion. After 10 minutes all Dio2 ${ }^{-/-}$points are significantly different versus wild-type animals by ANOVA. WT, wild-type; KO, knockout. a

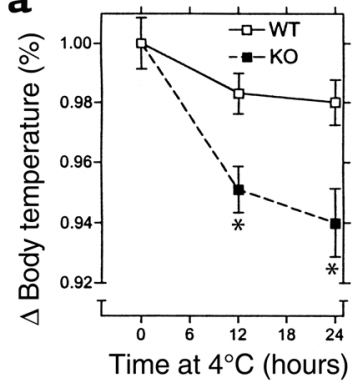

b

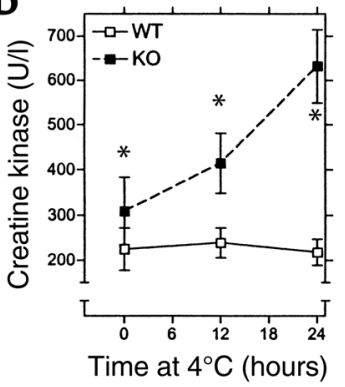

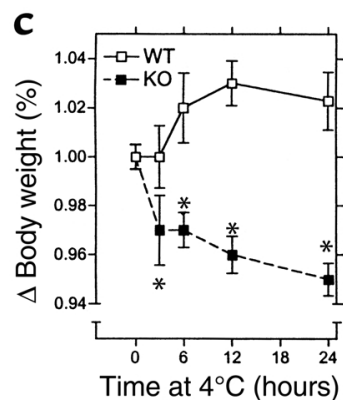

d

e
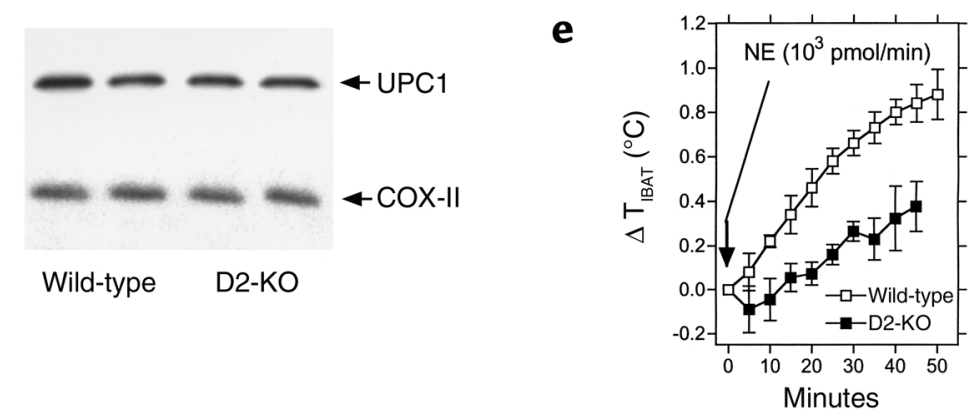

expected, Dio2 ${ }^{-/-}$mice had no D2 activity while IBAT D2 in wild-type mice increased approximately 17 -fold (Table 1). In both strains, plasma T4 and T3 remained constant (Table 1). Remarkably, the Dio2 ${ }^{-/-}$animals survived cold exposure although their core temperature fell about $2.3^{\circ} \mathrm{C}$, to $34.8^{\circ} \mathrm{C}$, by 24 hours (vs. a $\sim 0.7^{\circ} \mathrm{C}$ reduction in wild-type animals; Figure 1a), indicating that adaptive thermogenesis was deficient. More severe hypothermia was prevented by compensatory shivering as reflected by the increase in serum creatine kinase activity only in the D2-deficient animals (Figure 1b). Dio $2^{-/}$animals lost about $5 \%$ of their body weight during the 24-hour period, whereas there was no weight change in wild-type animals (Figure 1c). Food intake was monitored in both groups $(\sim 4.5 \mathrm{~g} / 24$ $\mathrm{h}$ /animal at $21^{\circ} \mathrm{C}$ in both groups), and, although it increased during cold exposure, no differences were found between Dio2 $2^{-/-}$and intact animals $(8.0 \pm 0.4$ $\mathrm{g} / 24 \mathrm{~h} /$ animal at $4^{\circ} \mathrm{C}$ in wild-type vs. $7.6 \pm 1.1 \mathrm{~g} / 24$ $\mathrm{h} /$ animal at $4^{\circ} \mathrm{C}$ in Dio2 $2^{--}$).

To evaluate the capacity for thermogenesis of BAT directly, we implanted a thermistor under the IBAT pad to quantitate heat production in response to a constant intravenous NE infusion $(1 \mathrm{nmol} / \mathrm{min})$ in anesthetized mice $(20,29)$. In wild-type mice, NE infusion elicited a rapid and progressive increase of about $0.9^{\circ} \mathrm{C}$ in BAT temperature (Figure 1e). On the other hand, thermogenesis is substantially impaired in Dio2 $2^{-/}$mice at all times studied with a maximal increase of only about $0.4^{\circ} \mathrm{C}$ (Figure 1e). Thus, impaired BAT thermogenesis in the D2-deficient animal is the cause of the hypothermia.

The absolute number of mitochondria in Dio2-/IBAT was normal as assessed by Southern blot analysis of the mitochondrial COX-II gene (Figure 1d). Total mitochondrial protein (Table 2) and UCP1 (Figure 1d) were also normal. However, the IBAT weighed about $40 \%$ more than in wild-type animals due to an approximately twofold increase in TG content (Table 2). This suggested an increase in the ratio of TG synthesis to lipolysis, which is also characteristic of BAT in chronically hypothyroid rats (30-32).

We then examined various other metabolic parameters essential to cellular thermogenesis in $\mathrm{Dio}^{-/-}$isolated brown adipocytes $(14,24,25)$. Both $\mathrm{O}_{2}$ consumption and lipolysis were reduced in response to NE; CL316,243, a selective activator of the $\beta 3$ receptors in brown adipocytes (33); or forskolin (Figure 2, a-f). In addition, while the basal content of UCP1 mRNA was not different between the two groups, there was an approximately $50 \%$ reduction of the acute increase in UCP1 mRNA in the Dio2 $2^{--}$adipocytes (Figure 2, $\mathrm{g}$ and

Table 2

Comparison of IBAT of Dio2 $2^{--}$and wild type mice acclimated at $21^{\circ} \mathrm{C}$.

\begin{tabular}{|c|c|c|c|c|c|c|c|c|c|}
\hline \multirow[t]{2}{*}{ Group } & \multicolumn{2}{|c|}{ Weight } & \multirow{2}{*}{$\begin{array}{l}\text { DNA } \\
(\mu \mathrm{g})\end{array}$} & \multicolumn{3}{|c|}{ Triglycerides } & \multicolumn{3}{|c|}{ Mitochondrial protein } \\
\hline & $(\mathrm{mg})$ & $/ \mathrm{BW} \times 10^{-3}$ & & $(\mathrm{mg})$ & $/ \mathrm{IBAT} \times 10^{-1}$ & $/ \mathrm{DNA} \times 10^{-1}$ & $(\mathrm{mg})$ & $/$ protein $\times 10^{-1}$ & $/ \mathrm{DNA} \times 10^{-1}$ \\
\hline $\begin{array}{l}\text { Wild-type } \\
\text { Dio2-/- }\end{array}$ & $\begin{array}{l}54 \pm 7 \\
67 \pm 9\end{array}$ & $\begin{array}{c}2.0 \pm 0.1 \\
2.8 \pm 0.2^{\mathrm{A}}\end{array}$ & $\begin{array}{c}73 \pm 4 \\
81 \pm 11\end{array}$ & $\begin{array}{c}19 \pm 2.9 \\
42 \pm 4.8^{A}\end{array}$ & $\begin{array}{l}3.5 \pm 0.8 \\
6.3 \pm 0.9^{\mathrm{A}}\end{array}$ & $\begin{array}{c}2.6 \pm 0.6 \\
5.2 \pm 0.8^{A}\end{array}$ & $\begin{array}{l}7.0 \pm 1.2 \\
7.4 \pm 1.1\end{array}$ & $\begin{array}{l}2.2 \pm 0.2 \\
1.7 \pm 0.1\end{array}$ & $\begin{array}{l}1.0 \pm 0.2 \\
0.9 \pm 0.1\end{array}$ \\
\hline
\end{tabular}

Values are the mean \pm SD of four to six animals per parameter. ${ }^{A} P<0.05$ versus wild-type animals by Student $t$ test. 
a

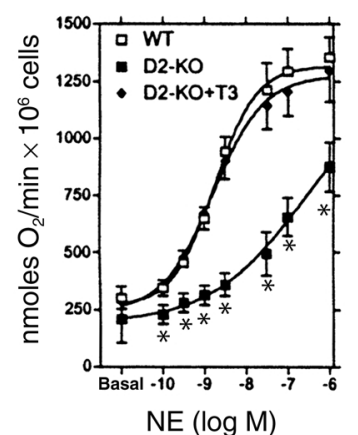

d

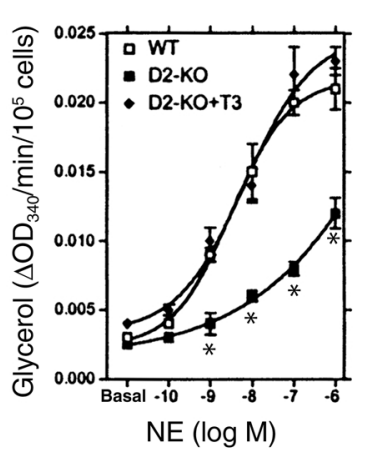

g

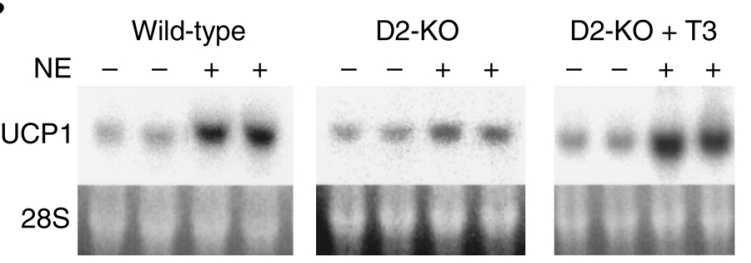

i

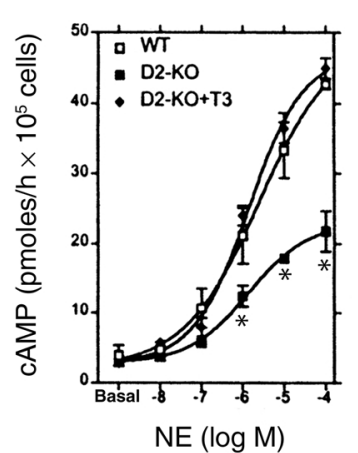

h). These deficits can all be explained by the impairment in cAMP generation in response to either NE, CL316,243, or forskolin (Figure 2, i-k). This points to impaired adenylyl cyclase function as the major cause of the reduction in thermogenesis.

To confirm that this abnormality was explained by intracellular T3 deficiency, a single injection of $5 \mu \mathrm{g}$ T3 per $10 \mathrm{~g} \mathrm{BW}$ was given intraperitoneally and brown adipocytes isolated 14 hours later. This dose was designed to saturate BAT TRs by increasing plasma T3 (34). While such short treatment has no effects on BAT function of intact rats (35), T3 injection increased the cAMP generation up to the levels seen in cells obtained from intact mice (Figure 2, i-k); it also increased the
C

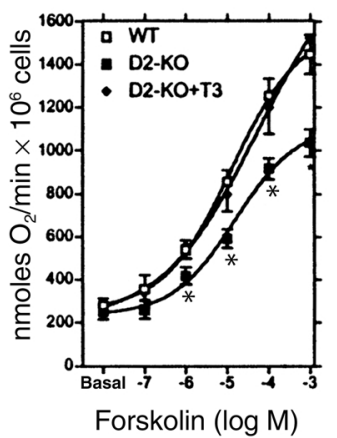

f

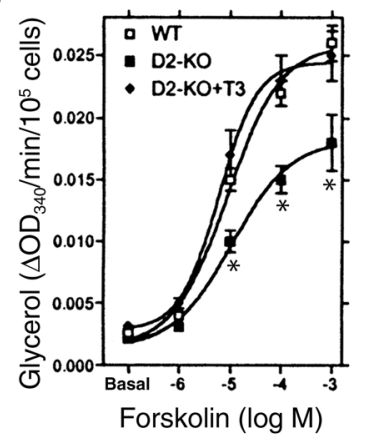

h

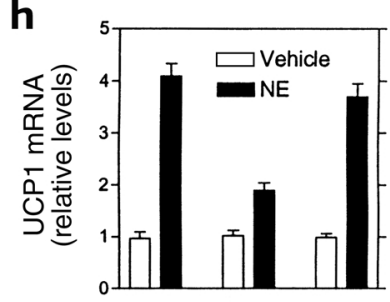

k

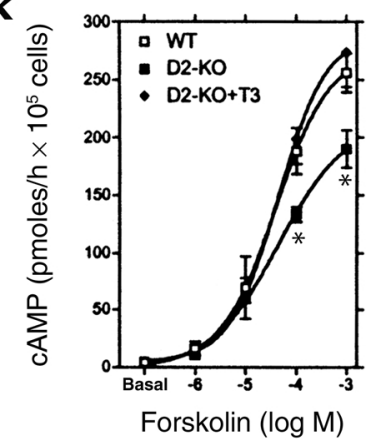

Figure 2

Metabolic responses of isolated brown adipocytes from $\mathrm{Dio} 2^{-/-}$and wild-type mice. ${ }^{*} P<0.05$ versus wild-type time point by ANOVA. (a-c) $\mathrm{O}_{2}$ consumption. Each point is the mean $\pm S D$ of four measurements of about 50,000 cells. (d-f) Glycerol released during incubation with NE or forskolin at $37^{\circ} \mathrm{C}$ for 1 hour. (g) The same conditions as in $\mathbf{d}$ except that about 500,000 cells were used. (h) Densitometry of the Northern blots shown in $\mathbf{g}$. (i-k) The same conditions as in $\mathbf{d}$ except that cAMP is shown. metabolic responses of the brown adipocytes (Figure 2, a-f). Remarkably, while T3 pretreatment did not alter the basal UCP1 mRNA, it also normalized the response of UCP1 mRNA to NE (Figure 2, $g$ and $h$ ).

\section{Discussion}

Type 2 deiodinase is well recognized as an important enzyme in BAT physiology, based largely on studies of hypothyroid rats. These studies have focused on its role in mitigating the effects of hypothyroxinemia on brown adipocytes $(6,9,11,19,30)$. While this is relevant for understanding the role of D2 in sustaining adaptive thermogenesis during iodine deficiency (36), there is little information defining the role of D2 in this 
process in iodine-sufficient animals $(35,37)$. The present results using the $\mathrm{Dio}^{-/-}$mouse provide the first direct evidence that $\mathrm{D} 2$ is also required for the normal response to cold stress in a normal mammal.

D2 activity generates a significant fraction of circulating T3 in rats (and presumably mice), and its absence could cause peripheral hypothyroidism (38). However, D2-deficient mice compensate by raising the plasma T4 concentration. They have normal serum T3, the main determinant of the thyroid status in skeletal muscle and other visceral organs, and therefore are systemically euthyroid. D2 is widely expressed in different areas of the CNS, where it accounts for $50-80 \%$ of the TR-bound T3 in the rat (39). It is not known whether the D2-deficient mice have CNS "hypothyroidism," but, if so, this could impair the neural relay of peripheral thermal information to the hypothalamus and/or the autonomic and behavioral thermoregulatory responses. The latter is not the case since the basal core temperature of Dio2 $2^{-/-}$mice is normal at $21^{\circ} \mathrm{C}\left(\sim 7^{\circ} \mathrm{C}\right.$ below thermoneutrality). In addition, during cold exposure $\left(4^{\circ} \mathrm{C}\right)$ they display characteristic nesting behavior, piloerection, and shivering, indicating that environmental and visceral temperatures are sensed, and appropriate responses generated, by the D2-deficient hypothalamus. However, the in vivo studies demonstrate that BAT from $\mathrm{Dio}^{-/-}$mice has an intrinsic defect in thermogenesis, failing to increase temperature normally during $\mathrm{NE}$ infusion (Figure 1e). This defect was confirmed in in vitro studies of isolated brown adipocytes (Figure 2).

Based on the importance of $\mathrm{T} 3$ for mitochondrial biogenesis (40) and UCP1 gene expression (41, 42), one might expect reduced UCP1 as the most likely cause of impaired BAT thermogenesis in these mice. However, both the BAT mitochondrial number and the basal UCP1 content are normal (Figure 1d; Table 2). The elevated TG content suggests that lipolysis is impaired, and the results in the adipocytes confirm this (Table 2; Figure 2, d-f). NE-stimulated $\mathrm{O}_{2}$ consumption and the normal increase in UCP1 mRNA in response to adrenergic agonists are all impaired. In BAT, $\beta 3$ adrenergic receptors account for as much as $50 \%$ of the maximal cAMP response to $\mathrm{NE}$, and they are increased in hypothyroid brown adipocytes (13). Therefore, the similar impairment in cAMP response to NE, the $\beta 3$ receptor-selective agonist CL316,243, and forskolin suggests that the major deficit is in the adenylyl cyclase rather than in the adrenergic receptor number or affinity. A similar impaired response is typical of hypothyroid brown adipocytes, and it is entirely reversed by $\mathrm{T} 3$ administration (12-14).

Thus, despite the normal plasma T3 and increased T4 concentrations, the BAT of the Dio2 ${ }^{-/-}$mouse is functionally hypothyroid in its response to cold stress. The D2-catalyzed T4 monodeiodination in BAT amplifies the cAMP response to adrenergic stimulation, which, in turn, enhances lipolysis and mitochondrial thermogenesis (Figure 3). The fact that isolated
Dio2 $2^{-/}$adipocytes cannot generate normal quantities of cAMP implies that tonic, D2-catalyzed T4-to-T3 conversion is required for this process. The normal plasma T3 concentration of the Dio2 $2^{-/}$animals is not sufficient for this purpose although it is adequate to sustain a normal UCP1 concentration. Recently, it has been shown that a preferential TR $\beta$ agonist, GC-1, normalizes UCP1, but not the impaired thyroid-sympathetic synergism in hypothyroid mice, suggesting that the former may be TR $\beta$-mediated and the latter dependent on TR $\alpha$ (20). The affinity of rat TR $\alpha$ for T3 is about fourfold lower than that for TR $\beta$ (43). Thus, chronic intracellular $\mathrm{T} 3$ production may be required to provide the higher concentration of intracellular hormone necessary to occupy the requisite number of $\alpha$ TRs in brown adipocytes. This suggests, in turn, that the thyroid-sympathetic synergism in BAT, and perhaps other tissues, is functionally linked to TR $\alpha$.

The D2-generated supplemental T3 also enhances the cAMP-generated acute increase in UCP1 mRNA via increased UCP1 gene transcription and by prolonging the mRNA half-life $(41,42)$. Since the Dio2 gene contains a cAMP-responsive element $(44,45)$, by increasing the cAMP response, the increased T3 also enhances a feed-forward cycle stimulating the increased synthesis of the short-lived D2 protein $\left(t_{1 / 2}\right.$ 20-30 min) $(23,46,47)$ (Figure 3$)$.

In mice with no UCP1 or dopamine $\beta$-hydroxylase, shivering alone is not sufficient to sustain core temperature for more than a few minutes $(17,48)$. Given the impaired response of Dio2 $2^{-/-}$BAT to cold stress, why does this mouse not succumb as do hypothyroid animals? The increased creatine kinase and the significant weight loss during cold stress in the $\mathrm{Dio}^{-/-}$mice indi-

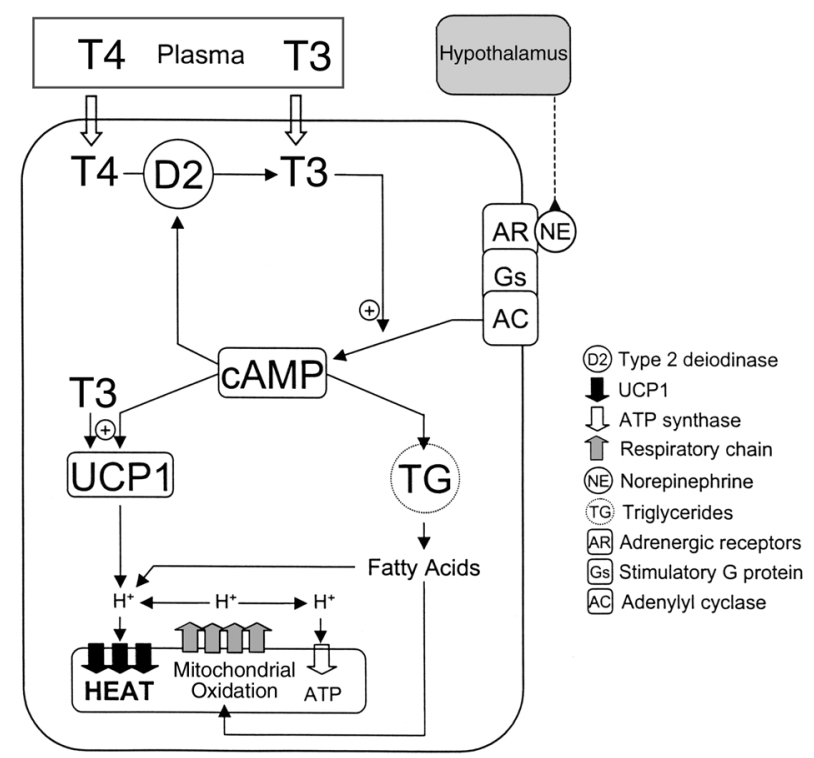

Figure 3

Role of the D2-generated intracellular T3 in the cellular thermogenesis in brown adipocytes. A plus sign within a circle indicates enhancement of that process by $\mathrm{T} 3$. 
cate that prolonged shivering provides the extra heat required for their survival. This suggests that $\mathrm{D} 2$ deficiency causes a milder defect in BAT heat production and does not eliminate nonshivering adaptive thermogenesis completely. This phenotype permits a better understanding of how thyroid hormone, UCP1, and cAMP coordinate in producing heat in response to cold. The superior thermal homeostasis of $\mathrm{Dio}^{-/-}$mice compared with hypothyroid rodents can be explained by the $50 \%$ reduction in UCP1 content and the enhanced thermodynamic efficiency of skeletal muscle in the latter $(11,49)$. This reduces the effectiveness of shivering as a protective thermogenic mechanism. In contrast, both UCP1 and shivering are normal in Dio $2^{-/-}$mice. However, shivering is a much less efficient mechanism for heat production than nonshivering thermogenesis due to the increased blood flow to superficial tissues and the associated convective heat loss (50). This can explain the loss of approximately $5 \%$ of the body weight of the Dio2 $2^{-/-}$mice in just 24 hours of cold exposure despite normal food ingestion, indicating that thermogenesis in BAT is a much more efficient mechanism for maintaining core temperature. Thus, the SNS-responsive Dio2 gene in BAT is essential to support its basal adrenergic responsiveness as well as the development of the intracellular thyrotoxicosis, thereby permitting thermal homeostasis of small mammals with a minimum of caloric expenditure.

\section{Acknowledgments}

We thank Valerie A. Galton (Department of Physiology, Dartmouth Medical School) and Donald L. St. Germain (Departments of Physiology and Medicine, Dart-

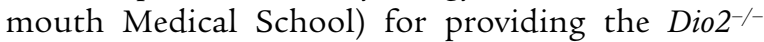
mouse. This work was supported by NIH grants DK36256, HD-09020, and DK-42271. We thank George Fischer (Brigham and Women's Hospital) for the creatine kinase assays.

1. Nicholls, D.G., and Locke, R.M. 1984. Thermogenic mechanisms in brown fat. Physiol. Rev. 64:1-64.

2. Himms-Hagen, J. 1990. Brown adipose tissue thermogenesis: interdisciplinary studies. FASEB J. 4:2890-2898.

3. Lowell, B.B., and Spiegelman, B.M. 2000. Towards a molecular understanding of adaptive thermogenesis. Nature. 404:652-660.

4. Nedergaard, J., et al. 2001. UCP1: the only protein able to mediate adaptive non-shivering thermogenesis and metabolic inefficiency. Biochim. Biophys. Acta. 1504:82-106.

5. Silva, J.E., and Larsen, P.R. 1983. Adrenergic activation of triiodothyronine production in brown adipose tissue. Nature. 305:712-713.

6. Bianco, A.C., and Silva, J.E. 1987. Nuclear 3,5,3'-triiodothyronine (T3) in brown adipose tissue: receptor occupancy and sources of T3 as determined by in vivo techniques. Endocrinology. 120:55-62.

7. Hernandez, A., and Obregon, M.J. 1996. Presence and mRNA expression of T3 receptors in differentiating rat brown adipocytes. Mol. Cell. Endocrinol. 121:37-46.

8. Silva, J.E., and Larsen, P.R. 1985. Potential of brown adipose tissue type II thyroxine $5^{\prime}$-deiodinase as a local and systemic source of triiodothyronine in rats. J. Clin. Invest. 76:2296-2305.

9. Bianco, A.C., and Silva, J.E. 1988. Cold exposure rapidly induces virtual saturation of brown adipose tissue nuclear T3 receptors. Am. J. Physiol. 255:E496-E503.

10. Sellers, E.A., and You, S.S. 1950. Role of the thyroid in metabolic responses to a cold environment. Am. J. Physiol. 163:81-91.

11. Bianco, A.C., and Silva, J.E. 1987. Intracellular conversion of thyroxine to triiodothyronine is required for the optimal thermogenic function of brown adipose tissue. J. Clin. Invest. 79:295-300.
12. Rubio, A., Raasmaja, A., Maia, A.L., Kim, K.R., and Silva, J.E. 1995. Effects of thyroid hormone on norepinephrine signaling in brown adipose tissue. I. Beta 1 - and beta 2-adrenergic receptors and cyclic adenosine $3^{\prime}, 5^{\prime}$ monophosphate generation. Endocrinology. 136:3267-3276.

13. Rubio, A., Raasmaja, A., and Silva, J.E. 1995. Thyroid hormone and norepinephrine signaling in brown adipose tissue. II. Differential effects of thyroid hormone on beta 3-adrenergic receptors in brown and white adipose tissue. Endocrinology. 136:3277-3284.

14. Carvalho, S.D., Bianco, A.C., and Silva, J.E. 1996. Effects of hypothyroidism on brown adipose tissue adenylyl cyclase activity. Endocrinology. 137:5519-5529.

15. Ricquier, D., and Kader, J.C. 1976. Mitochondrial protein alteration in active brown fat: a sodium dodecyl sulfate-polyacrylamide gel electrophoretic study. Biochem. Biophys. Res. Commun. 73:577-583.

16. Heaton, G.M., Wagenvoord, R.J., Kemp, A., Jr., and Nicholls, D.G. 1978 Brown-adipose-tissue mitochondria: photoaffinity labeling of the regulatory site of energy dissipation. Eur. J. Biochem. 82:515-521.

17. Enerback, S., et al. 1997. Mice lacking mitochondrial uncoupling protein are cold-sensitive but not obese. Nature. 387:90-94.

18. Garlid, K.D., Jaburek, M., and Jezek, P. 1998. The mechanism of proton transport mediated by mitochondrial uncoupling proteins. FEBS Lett. 438:10-14.

19. Carvalho, S.D., Kimura, E.T., Bianco, A.C., and Silva, J.E. 1991. Central role of brown adipose tissue thyroxine $5^{\prime}$-deiodinase on thyroid hormone-dependent thermogenic response to cold. Endocrinology. 128:2149-2159.

20. Ribeiro, M.O., et al. 2001. Thyroid hormone-sympathetic interaction and adaptive thermogenesis are thyroid hormone receptor isoform-specific. J. Clin. Invest. 108:97-105.

21. Bianco, A.C., Carvalho, S.D., Carvalho, C.R., Rabelo, R., and Moriscot, A.S. 1998. Thyroxine 5'-deiodination mediates norepinephrine-induced lipogenesis in dispersed brown adipocytes. Endocrinology. 139:571-578.

22. Schneider, M., et al. 2001. Targeted disruption of the type 2 selenodeiodinase gene (Dio2) results in a phenotype of pituitary resistance to thyroxine. Mol. Endocrinol. In press.

23. Curcio, C., et al. 2001. The human type 2 iodothyronine deiodinase is a selenoprotein highly expressed in a mesothelioma cell line. J. Biol. Chem. 276:30183-30187.

24. Noronha, M., Raasmaja, A., Moolten, N., and Larsen, P.R. 1991. Triiodothyronine causes rapid reversal of alpha $1 /$ cyclic adenosine monophosphate synergism on brown adipocyte respiration and type II deiodinase activity. Metabolism. 40:1327-1332.

25. Bianco, A.C., Kieffer, J.D., and Silva, J.E. 1992. Adenosine 3',5'monophosphate and thyroid hormone control of uncoupling protein messenger ribonucleic acid in freshly dispersed brown adipocytes. Endocrinology. 130:2625-2633.

26. Sundin, U., Mills, I., and Fain, J.N. 1984. Thyroid-catecholamine interactions in isolated rat brown adipocytes. Metabolism. 33:1028-1033.

27. Bradford, M.M. 1976. A rapid and sensitive method for the quantitation of microgram quantities of protein utilizing the principle of protein-dye binding. Anal. Biochem. 72:248-254.

28. Giles, K.W., and Myers, A. 1965. An improved diphenilamine method for the estimation of deoxyribonucleic acid. Nature. 206:93.

29. Ribeiro, M.O., et al. 2000. Evidence of UCP1-independent regulation of norepinephrine-induced thermogenesis in brown fat. Am. J. Physiol. Endocrinol. Metab. 279:E314-E322.

30. Bianco, A.C., and Silva, J.E. 1987. Optimal response of key enzymes and uncoupling protein to cold in BAT depends on local T3 generation. Am. J. Physiol. 253:E255-E263.

31. Freake, H.C., and Oppenheimer, J.H. 1987. Stimulation of S14 mRNA and lipogenesis in brown fat by hypothyroidism, cold exposure, and cafeteria feeding: evidence supporting a general role for S14 in lipogenesis and lipogenesis in the maintenance of thermogenesis. Proc. Natl. Acad. Sci. USA. 84:3070-3074.

32. Carvalho, S.D., Negrao, N., and Bianco, A.C. 1993. Hormonal regulation of malic enzyme and glucose-6-phosphate dehydrogenase in brown adipose tissue. Am. J. Physiol. 264:E874-E881.

33. Rohlfs, E.M., Daniel, K.W., Premont, R.T., Kozak, L.P., and Collins, S. 1995. Regulation of the uncoupling protein gene (Ucp) by beta 1, beta 2 , and beta 3 -adrenergic receptor subtypes in immortalized brown adipose cell lines. J. Biol. Chem. 270:10723-10732.

34. Maia, A.L., Kieffer, J.D., Harney, J.W., and Larsen, P.R. 1995. Effect of $3,5,3^{\prime}$-triiodothyronine (T3) administration on dio1 gene expression and T3 metabolism in normal and type 1 deiodinase-deficient mice. Endocrinology. 136:4842-4849.

35. Branco, M., Ribeiro, M., Negrao, N., and Bianco, A.C. 1999. 3,5,3'-Triiodothyronine actively stimulates UCP in brown fat under minimal sympathetic activity. Am. J. Physiol. 276:E179-E187.

36. Pazos-Moura, C.C., et al. 1991. Effect of iodine deficiency and cold exposure on thyroxine $5^{\prime}$-deiodinase activity in various rat tissues. Am.J. Physiol. 260:E175-E182.

37. Reiter, R.J., et al. 1990. Inhibition of 5'-deiodination of thyroxine sup- 
presses the cold-induced increase in brown adipose tissue messenger ribonucleic acid for mitochondrial uncoupling protein without influencing lipoprotein lipase activity. Endocrinology. 126:2550-2554.

38. Nguyen, T.T., Chapa, F., and DiStefano, J.J., III. 1998. Direct measurement of the contributions of type I and type II 5 -deiodinases to whole body steady state 3,5,3'-triiodothyronine production from thyroxine in the rat. Endocrinology. 139:4626-4633.

39. Larsen, P.R., Silva, J.E., and Kaplan, M.M. 1981. Relationships between circulating and intracellular thyroid hormones: physiological and clinical implications. Endocr. Rev. 2:87-102.

40. Klingenspor, M., et al. 1996. Biogenesis of thermogenic mitochondria in brown adipose tissue of Djungarian hamsters during cold adaptation. Biochem. J. 316:607-613.

41. Bianco, A.C., Sheng, X., and Silva, J.E. 1988. Triiodothyronine amplifies norepinephrine stimulation of uncoupling protein gene transcription by a mechanism not requiring protein synthesis. J. Biol. Chem. 263:18168-18175.

42. Rehnmark, S., Bianco, A.C., Kieffer, J.D., and Silva, J.E. 1992. Transcriptional and posttranscriptional mechanisms in uncoupling protein mRNA response to cold. Am. J. Physiol. 262:E58-E67.

43. Schueler, P.A., Schwartz, H.L., Strait, K.A., Mariash, C.N., and Oppenheimer, J.H. 1990. Binding of 3,5,3'-triiodothyronine $\left(T_{3}\right)$ and its analogs to the in vitro translational products of c-erbA protooncogenes: differences in the affinity of the $\alpha$-and $\beta$-forms for the acetic acid analog and failure of the human testis and kidney $\alpha-2$ products to bind $\mathrm{T}_{3} . \mathrm{Mol}$. Endocrinol. 4:227-234.

44. Bartha, T., et al. 2000. Characterization of the $5^{\prime}$-flanking and $5^{\prime}$-untranslated regions of the cyclic adenosine $3^{\prime}, 5^{\prime}$-monophosphate-responsive human type 2 iodothyronine deiodinase gene. Endocrinology. 141:229-237.

45. Song, S., Adachi, K., Katsuyama, M., Sorimachi, K., and Oka, T. 2000. Isolation and characterization of the $5^{\prime}$-upstream and untranslated regions of the mouse type II iodothyronine deiodinase gene. Mol. Cell. Endocrinol. 165:189-198.

46. St. Germain, D.L. 1988. The effects and interactions of substrates, inhibitors, and the cellular thiol-disulfide balance on the regulation of type II iodothyronine 5'-deiodinase. Endocrinology. 122:1860-1868.

47. Hernandez, A., and Obregon, M.J. 1996. T3 potentiates the adrenergic stimulation of type II $5^{\prime}$-deiodinase activity in cultured rat brown adipocytes. Am. J. Physiol. 271:E15-E23.

48. Thomas, S.A., and Palmiter, R.D. 1997. Thermoregulatory and metabolic phenotypes of mice lacking noradrenaline and adrenaline. Nature. 387:94-97.

49. Everts, M.E., van Hardeveld, C., Ter Keurs, H.E., and Kassenaar, A.A. 1981. Force development and metabolism in skeletal muscle of euthyroid and hypothyroid rats. Acta Endocrinol. (Copenh.) 97:221-225.

50. Bruck, K. 1998. Neonatal thermal regulation. In Fetal and neonatal physiology. R.A. Polin and W.W. Fox, editors. W.B. Saunders Co. Philadelphia, Pennsylvania, USA. 676-702. 